\title{
Climate researcher takes academy hot seat
}

Geoff Brumfiel, Washington

Ralph Cicerone, an atmospheric chemist and leading climate-change researcher, is set to become the next president of the US National Academy of Sciences.

The academy's council announced the nomination of Cicerone, who is currently chancellor of the University of California, Irvine, on 15 June. Once elected - usually a formality under the academy's system - he will serve a six-year term from July 2005, replacing the current president, molecular biologist Bruce Alberts.

The 2,000-member academy is generally considered to be the United States' pre-eminent scientific body, and is regularly asked by the government to provide scientific advice on issues ranging from stem cells to global warming. The 61-year-old Cicerone will be the first climate-change scientist to become its president.

His nomination comes after a period in which the scientific community has clashed with the federal government over climate change. In 2001, Cicerone led an academy study that angered the Bush administration by confirming the likelihood that human activities are causing global warming.

Cicerone is certainly no stranger to politically sensitive research. In the early 1970s, he was among the first atmospheric chemists to tie chlorine to the destruction of the ozone layer, according to Sherwood Rowland, a chemist at UC Irvine who won the 1995 Nobel Prize in Chemistry for his work on ozone depletion. Cicerone testified at the

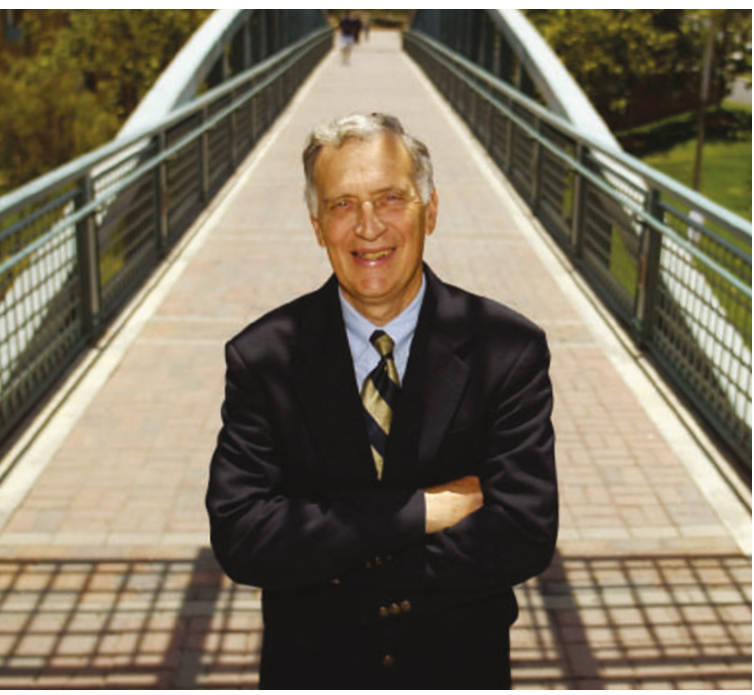

pob: Ralph Cicerone will succeed Bruce Alberts in July 2005.

our panel would be seen as carrying the water for somebody's agenda," Cicerone says. But in the end, the group delivered a scientifically precise document that provided little support for the administration's position. "It was a very honest report," says Eileen Claussen, president of the Pew Center on Global Climate Change in Washington DC.

As chair of the 2001 study, Cicerone did "exactly what we want a president to be able to do", says Peter Raven, head of the Missouri Botanical Garden in St Louis and chair of the academy's nominating committee. Raven says that Cicerone's proven ability as a fundraiser and manager during his six years at UC Irvine also strengthened his candidacy.

As well as addressing politically

time about the impact of chlorofluorocarbons (CFCs) on the ozone layer.

Colleagues say that Cicerone's easy-going personality and skill as a consensus-builder have helped to maintain his credibility with policy-makers. "He's very practised in the relationship between scientific discovery and sound public policy," says James Anderson, an atmospheric chemist at Harvard University in Cambridge, Massachusetts, who worked with Cicerone at the University of Michigan.

The 2001 climate-change report was requested by President Bush just before a trip to Europe where he sought to repair damage done by the US withdrawal from the Kyoto Protocol on climate change (see Nature 411, $725 ; 2001)$. "There were people who thought awkward scientific issues, Cicerone pledges continued attention to education and international outreach — areas emphasized by Alberts during his two six-year terms. The academy produced a set of standards in 1996 that has strongly influenced science education in US schools, and Alberts helped form the InterAcademy Council, an international consortium of science academies, in 2000.

But it is Cicerone's experience in tackling tricky areas of science policy that most excites his fellow academy members. "He's quite experienced on Washington affairs," says Frank Press of the Washington Advisory Group, who served as president of the academy from 1981 to 1993 . "He is a balanced, unbiased person, and that's what the academy needs these days."

\section{Last-ditch funding keeps ocean drilling project afloat}

\section{David Cyranoski, Yokohama}

The world's largest ocean-drilling research team was given a crucial injection of cash last week, saving the programme from losing its only dedicated drilling ship.

The scientific planning committee of the Integrated Ocean Drilling Program (IODP) met in Yokohama to rank 19 science proposals, each one vying for drilling time during the fiscal year starting in October 2006. But the committee faced a serious problem - not having enough money for a ship to host these projects.

The IODP's current ship, the JOIDES Resolution - which is provided by the United States as part of its contribution to the multinational project - was assured of funding only until May 2005.

The IODP would face heavy competition and high prices if it then tried to commission a replacement ship, says Frank Rack, director of drilling programs for the US Joint Oceanographic Institutions, because high oil prices are driving oil companies to rent drilling ships for exploration.

The meeting was close to becoming nothing more than "an educational exercise", says Mike Coffin, a geophysicist at the University of Tokyo and chair of the planning committee.

But representatives of the National Science Foundation, which funds US involvement in the programme, announced they would provide enough money to keep the JOIDES Resolution afloat. The amount is not clear and will depend on the cost of the proposals selected, but it came as a relief to scientists who feared that the projects they were ranking would be lost to a gap in funding. Instead, the committee now has to rush through plans for two additional cruises in 2005 and a possibility of six in 2006.

"We have to scramble," says Terrence Quinn, a committee member from the University of South Florida. "You don't want to have a boat without projects to go on it."

The top three projects picked are all geophysics studies - something of a surprise given the growing presence of climate studies in ocean drilling projects, says Coffin. The top priority is to drill through the Guatemala Basin, all the way through the ocean crust, revealing details of magma formation, hydrothermal effects and tectonic processes. Investigations into the earthquake-generating zone in the Nankai Trough off Japan are next on the list. 